International Journal of Public Health Excellence (IJPHE)

Vol. 1, No. 1, January 2022, pp. 06 11

Journal homepage: https://ejournal.ipinternasional.com/index.php/ijphe/

ISSN: 2809-9826, DOI: https://doi.org/10.55299/ijphe.v1i1.3

\title{
The Effect of Simplicia Leaves of Papaya (Carica Papaya L) on Adequacy of Breast Milk in Babies Aged 6 Months
}

\author{
Novita Sari Batubara ${ }^{1}$, Nur Aliyah Rangkuti ${ }^{2}$, Rya Anastasya Siregar ${ }^{3}$, Elvi Suryani ${ }^{4}$, Ratna Dewi Siregar ${ }^{5}$ \\ Maryam Latifah Harahap ${ }^{6}$ \\ ${ }^{1}$ Health faculty, Aufa Royhan University, Indonesia \\ ${ }^{2}$ Health faculty, Aufa Royhan University, Indonesia \\ ${ }^{3}$ Health faculty, Aufa Royhan University, Indonesia \\ ${ }^{4}$ D3 Midwifery Study Program, Darmais Padangsidimpuan Midwifery Academy, Indonesia \\ ${ }^{5}$ Health faculty, Aufa Royhan University, Indonesia \\ ${ }^{6}$ D3 Midwifery Study Program, Darmais Padangsidimpuan Midwifery Academy, Indonesia
}

\begin{abstract}
Article Info
ABSTRACT

Article history:

Received December 01, 2021

Revised December 16, 2021

Accepted December 20, 2021

\section{Corresponding Author:}

Novita Sari Batubara

Health faculty, Aufa Royhan

University Padangsidimpuan,

Padangsidimpuan, Indonesia

novitabatubara87@gmail.com

Adequacy of breast milk is the condition of the baby or mother showing several signs that indicate satisfaction in the production or consumption of breast milk. Infants aged 6 months, can be judged to have adequate breastfeeding, one of which is marked by the baby drinking breast milk every 2-3 hours or in 24 hours at least getting breast milk 8 times in the first 2-3 weeks. Papaya leaf simplicia can be one way to increase the rate of secretion and milk production and a strategy to overcome the failure of exclusive breastfeeding caused by low milk production. Based on this background, the researchers conducted a study on the effect of papaya leaf simplicia (Carica Papaya L.) on the adequacy of breast milk in infants aged 6 months. This type of research is a quasi-experiment with a one-group pretest-posttest design. The results showed that there was an effect of Papaya Leaf Simplicia (Carica Papaya L.) on the adequacy of breast milk in infants aged 6 months $(\operatorname{sig}=0,000<\alpha=0,05)$. This shows that consuming Papaya Leaf Simplicia (Carica Papaya L.) is proven to be effective in increasing the adequacy of breast milk.
\end{abstract}

Keywords:

Adequacy of breast milk, Papaya Leaf Simplicia, Baby aged 6 months

This article is licensed under a Creative Commons AttributionShareAlike 4.0 International License..

\section{INTRODUCTION}

The United Nations Children's Fund (UNICEF) and the World Health Organization (WHO) recommend that children should only be breastfed with breast milk (ASI) since birth for six months, without adding and/or replacing with other foods or drinks (except drugs, vitamins and minerals). . This is done in order to reduce child morbidity and mortality. Efforts to improve nutrition through the implementation of exclusive breastfeeding have been mandated through Law NO. 36 of 2009 states that babies have the right to exclusive breastfeeding and Government Regulation No. 33 of 2012 states that the Government, Provincial Government, and District/City Governments are responsible for the exclusive breastfeeding program.[5][11][16]

Data from the World Health Organization (WHO) in 2015 showed that the infant morbidity rate in the world was 43 deaths per 1000 live births. In Indonesia, the infant morbidity rate was 32 per 1000 live births in 2015. In 2013 there were 5865 cases of infant morbidity per year. In 2014 it fell to 5666 cases, in 2015 it became 5571 cases, and in 2016 it became 5485 cases. From 2017 to June there were 2,182 cases.

One of the goals of the SDG's (Sustainable Development Goal's) program is to end all forms of malnutrition with a strategic plan (renstra) to increase the percentage of infants less than 6 months old who receive exclusive breastfeeding from $42 \%$ to $50 \%$ in 2019.[1][20]

Nationally, the coverage of infants receiving exclusive breastfeeding is $61.33 \%$. This figure has exceeded the 2017 Strategic Plan target of 44\%. The highest percentage of exclusive breastfeeding coverage is in West Nusa Tenggara $(87.35 \%)$, while the lowest percentage is in Papua $(15.32 \%)$, while North Sumatra is at the percentage $(45.74 \%)$. There are five provinces that have not yet reached the 2017 Strategic Plan target (Ministry of Health of the Republic of Indonesia 2018). The purpose of this study was to determine the effect of papaya leaf simplicia (Carica 
Papaya L.) on the adequacy of breast milk in infants aged 6 months in the working area of Gunung Tua Health Center, Kab. North Padang Lawas. [7][5][23]

\section{METHOD}

This type of research is a quasi-experiment with a one-group pretest-posttest design. In this design, one group is selected as the object of research. In this study, respondents will find out the effect of papaya leaf simplicia (CARICA PAPAYA L) on the adequacy of breast milk in infants aged 6 in the working area of the Gunungtua Health Center, Padang Bolak District, North Padang Lawas Regency.[15][14]

This research was conducted in the Gunung Tua Health Center Working Area in 2021. Based on the initial survey, the health center has never provided non-pharmacological therapy to mothers who have babies aged 6 months.[17]

Based on the above calculations, the number of samples in this study were 20 mothers. To avoid a drop out sample, $10 \%$ of the calculation sample is added, which is 3 . The total sample needed in this study is 23 mothers.

The sampling technique used the purposive sampling method, namely adjusting to the sample criteria. Collecting data using an observation sheet and data analysis using the Kolmogrov-Smirnov test.[21][13]

\section{RESULTS AND DISCUSSION}

Table 1. Results Characteristics of Mother Respondents

\begin{tabular}{|c|c|c|c|}
\hline Indicator & Category & Frequency & Percentage $(\%)$ \\
\hline \multirow{4}{*}{ Age } & $21-24$ years old & 6 & 26,1 \\
\hline & $25-29$ years old & 8 & 34,8 \\
\hline & $30-34$ years old & 7 & 30,4 \\
\hline & $35-39$ years old & 2 & 8,7 \\
\hline \multirow{3}{*}{ Education } & junior high school & 2 & 8,7 \\
\hline & senior High School & 16 & 69,6 \\
\hline & College & 5 & 21,7 \\
\hline \multirow{3}{*}{ Work } & Housewife & 11 & 47,8 \\
\hline & Private employees & 9 & 39,1 \\
\hline & entrepreneur & 3 & 13 \\
\hline \multirow{2}{*}{ Income } & $\begin{array}{l}<\text { regional minimum } \\
\text { wage }\end{array}$ & 10 & 43,5 \\
\hline & $\begin{array}{l}\geq \text { regional minimum } \\
\text { wage }\end{array}$ & 13 & 56,5 \\
\hline \multirow{3}{*}{ Ethnic group } & Batak & 14 & 60,9 \\
\hline & Jawa & 3 & 13 \\
\hline & Minangkabau & 6 & 26,1 \\
\hline \multirow{2}{*}{ Religion } & Islam & 18 & 78,3 \\
\hline & Christian & 5 & 21,7 \\
\hline
\end{tabular}

Based on the data presented in Table 1, it is known that from a total of 23 respondents in this study, the results showed that most of the respondents were aged 25 - 29 years, namely 34.8\%. Then respondents aged $30-34$ years amounted to $30.4 \%$. As many as $26.1 \%$ of respondents aged $21-24$ years. The remaining $8.7 \%$ of respondents aged 35 - 39 years.it is known that from a total of 23 respondents in this study, the results showed that most of the respondents had the latest high school education, which was $69.6 \%$. Then, $21.7 \%$ of respondents had a college education. As many as $8.7 \%$ of respondents have the last education of junior high school.

Based on the data presented in Table 1, it is known that from a total of 23 respondents in this study, the results showed that most of the respondents worked as housewives, namely $47.8 \%$. Then the respondents who work as private employees are $39.1 \% .13 .0 \%$ of the respondents work as entrepreneurs.

It is known that from a total of 23 respondents in this study, the results showed that most of the respondents had an income of Regional Minimum Wage, which was 56.5\%. Then the respondent's income is < Regional Minimum Wage, which is $43.5 \%$. from a total of 23 respondents in this study, the results showed that most of the respondents came from the Batak tribe, which was $60.9 \%$. Then $26.1 \%$ of respondents came from the Minangkabau tribe. The remaining $13.0 \%$ of respondents came from the Javanese ethnicity. of the total 23 respondents in this study, the results showed that most of the respondents were Muslim, which was $78.3 \%$. Then $21.7 \%$ of respondents are Christian.

Table 2. Results Characteristics of Infant Respondents

\begin{tabular}{clcc}
\hline Indicator & Category & Frequency & $\begin{array}{c}\text { Percentage } \\
(\boldsymbol{\%})\end{array}$ \\
\hline \multirow{2}{*}{ Gender } & male & 12 & 52,2 \\
& Female & 11 & 47,8 \\
& 1 month & 1 & 4,3 \\
\multirow{2}{*}{ Age } & 2 month & 3 & 13,0 \\
& 3 month & 5 & 21,7 \\
& 4 month & 6 & 26,1 \\
& 5 month & 4 & 17,4 \\
& 6 month & 4 & 17,4 \\
\hline
\end{tabular}


Based on the data presented in Table 2, it is known that from a total of 23 respondents in this study, the results showed that most of the respondents had male children, namely $52.2 \%$ and the remaining $47.8 \%$ of respondents had female children.

In terms of children's age, most of the respondents have children aged 4 months by $26.1 \%$. Then respondents who have children aged 3 months by $21.7 \%$. Each $17.4 \%$ of respondents have children aged 5 months and 6 months. The remaining $13.0 \%$ of respondents have children aged 2 months and only $4.3 \%$ of respondents have children aged 1 month.

Table 3. Results of the Characteristics of Infant Respondents on Infant Weight and Height

\begin{tabular}{cccccc}
\hline Characteristics & N & Minimum & Maximum & Mean & Std. Deviation \\
\hline Weight & 23 & 3,40 & 8,00 & 5,8000 & 1,36048 \\
Height & 23 & 50,00 & 67,00 & 58,5652 & 4,52092
\end{tabular}

Based on the results, it can be seen that the baby's weight owned by the respondents in this study was the thinnest at $3.40 \mathrm{~kg}$ and the heaviest at $8.00 \mathrm{~kg}$. The average baby weight of the respondents in this study was $5.8000 \mathrm{~kg}$ with a standard deviation of $1.36048 \mathrm{~kg}$. The standard deviation value which is smaller than the average indicates that the variation in infant weight tends to be small.

From the results it can also be seen that the baby's height owned by the respondents in this study was the shortest $50.00 \mathrm{~cm}$ and the highest at $67.00 \mathrm{~cm}$. The average weight and height of the babies owned by the respondents in this study was $58.5652 \mathrm{~cm}$ with a standard deviation of $4.52092 \mathrm{~cm}$. The standard deviation value which is smaller than the average indicates that the variation in infant height tends to be small.

\subsection{Descriptive Analysis}

Before giving Papaya Leaf Simplicia (Carica Papaya L.) the adequacy of mother's milk was first measured to get the pretest nutritional adequacy. Then the nutritional adequacy was measured. The following are the results of measuring nutritional adequacy before and after being given Papaya Leaf Simplicia (Carica Papaya L.)[3][12]

Table 4. Descriptive Analysis of Breast Milk Adequacy

\begin{tabular}{cccccc}
\hline Test & N & Minimum & Maximum & Mean & $\begin{array}{c}\text { Std. } \\
\text { Deviation }\end{array}$ \\
\hline $\begin{array}{c}\text { Breastmilk } \\
\text { Adequacy } \\
\text { Pretest }\end{array}$ & 23 & 580 & 800 & 697,174 & 62,1001 \\
$\begin{array}{c}\text { Breastmilk } \\
\text { Adequacy } \\
\text { Posttest }\end{array}$ & 23 & 560 & 900 & 757,391 & 90,46433 \\
\hline
\end{tabular}

The lowest value of pretest Nutrition adequacy is 580 and the highest value is 800 . The average nutritional adequacy value before the experiment is 697,174 with a standard deviation of 62,1001. After being given an experiment, namely in the form of giving Simplicia Papaya Leaves (Carica Papaya L.), a final test was carried out to determine the nutritional adequacy value or Posttest. In the Posttest, the lowest value of nutritional adequacy was 560 and the highest value was 900 . The average value of nutritional adequacy in the Posttest group was 757,391 with a standard deviation of 90,46433.[18]

\subsection{Bivariate Analysis}

The Bivariate Analysis explains the description of each variable used in this study and examines the effect of Papaya Leaf Simplicia (Carica Papaya L.) on the adequacy of breast milk in infants aged 6 months. The results of the Bivariate Analysis can be explained as follows:[25]

Table 5. Description of Breast Milk Adequacy Variables

\begin{tabular}{ccccc}
\hline \multirow{2}{*}{ Category } & \multicolumn{2}{c}{ Not Consumed } & \multicolumn{2}{c}{ Consumed } \\
\cline { 2 - 5 } & Frequency & Percentage & Frequency & Percentage \\
\hline Not enough & 19 & 82,6 & 10 & 43,5 \\
Enough & 4 & 17,4 & 13 & 56,5 \\
\hline
\end{tabular}

Based on the data presented in Table 5, it is known that from a total of 23 respondents in this study, the results showed that most of the respondents before consuming Papaya Leaf Simplisia (Carica Papaya L.) had breast milk in the less category. However, after consuming Papaya Leaf Simplisia (Carica Papaya L.), most of the respondents had sufficient breast milk. For more details can be seen in the following graph: 


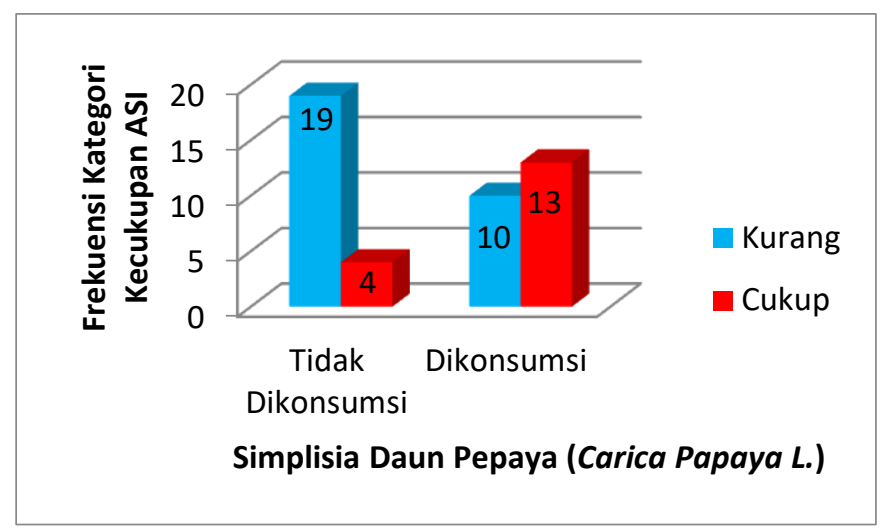

Figure 1. Description of Breast Milk Adequacy Variables

Based on the results on the graph, it is clearly known that after consuming Papaya Leaf Simplicia (Carica Papaya L.) there is an increase in the adequacy of breast milk. It is proven by the amount of breast milk that is quite increased after consuming Papaya Leaf Simplicia (Carica Papaya L.).

\subsubsection{Testing Requirements Analysis}

Testing requirements analysis is carried out to determine the parametric feasibility before testing the hypothesis

\section{Normality Test}

The normality assumption test is intended to determine whether the resulting data is normally distributed or not. To detect whether the data is normally distributed or not, it can be seen through the statistical test of Saphiro Wilk's. Data is declared normally distributed if the probability value is more than alpha (5\% or 0.05$)$. The following are the results of testing the normality assumption through Saphiro Wilk's test statistics:

Table 6. Normality Test Results

\begin{tabular}{ccc}
\hline Group & Statistics & Probability \\
\hline Not Consumed & 0,954 & 0,357 \\
Consumed & 0,969 & 0,665 \\
\hline
\end{tabular}

Based on the table above, it can be seen that the normality test produces a probability greater than alpha (5\% or 0.05 ). So that the data on the adequacy of breastfeeding both at the pretest and posttest were declared to be normally distributed. So the assumption of normality is met. Thus, testing the effect of Papaya Leaf Simplicia (Carica Papaya L.) on Adequacy of Breastfeeding in Infants Age 6 Months in the Working Area of the Gunung Tua Health Center, Kab. North Padang Lawas in 2021 using paired t test analysis.

\section{Homogeneity Test}

The homogeneity assumption test is intended to determine whether the resulting data has a homogeneous variance. To detect whether the pretest and posttest group data have homogeneous variance or not, it can be seen through the Levene's Test statistic. The data is declared to have a homogeneous variance if the probability value is more than alpha (5\% or 0.05$)$. The following are the results of testing the normality assumption through Levene's Test statistics:

Table 7. Homogeneity Test Results

\begin{tabular}{lcc}
\multicolumn{1}{c}{ Test } & Statistics & Probability \\
\hline Based on Mean & 4,003 & 0,052 \\
Based on Median & 3,664 & 0,062 \\
Based on Median and & 3,664 & 0,063 \\
with adjusted df & 3,870 & 0,055 \\
$\begin{array}{l}\text { Based on trimmed } \\
\text { mean }\end{array}$ & \\
\hline
\end{tabular}

Based on the table above, it can be seen that the homogeneity test on all tests resulted in a probability greater than alpha $(5 \%$ or 0.05$)$. So that the data on the adequacy of breast milk is stated to have a homogeneous variance. So that the assumption of homogeneity is met. Thus, testing the effect of Papaya 
Leaf Simplicia (Carica Papaya L.) on Adequacy of Breastfeeding in Infants Age 6 Months in the Working Area of the Gunung Tua Health Center, Kab. North Padang Lawas using paired t test analysis.[17]

\subsubsection{Data Analysis Results}

Data analysis in this study aims to test the research hypothesis. The data analysis was intended to simultaneously test the effect of Papaya Leaf Simplicia (Carica Papaya L.) on the adequacy of breast milk in infants aged 6 months in the working area of Gunung Tua Health Center, Kab. North Padang Lawa. Data analysis using Wilcoxon analysis. The analysis is presented as follows.[17]

1. Test the Effect of Papaya Leaves Simplicia (Carica Papaya L.) on Breast Milk Adequacy

Testing the effect of papaya leaf simplicia (Carica papaya 1.) on the adequacy of breast milk in infants aged 6 months in the working area of the Gunung Tua Public Health Center, North Padang Lawas Regency in 2021, was carried out using Wilcoxon analysis with the following hypothesis:

H0 : There is no effect of Papaya Leaf Simplicia (Carica Papaya L.) on the adequacy of breast milk in infants aged 6 months

H1 : There is an effect of Papaya Leaf Simplicia (Carica Papaya L.) on the adequacy of breast milk in infants aged 6 months

The test criteria state that if the significance value is level of significance (alpha $=5 \%$ or 0.05 ), then $\mathrm{H} 0$ is rejected, so it can be stated that there is an effect of Papaya Leaf Simplicia (Carica Papaya L.) on the adequacy of breast milk in infants aged 6 months.

The results of the test of the effect of Papaya Leaf Simplicia (Carica Papaya L.) on the adequacy of breast milk in infants aged 6 months can be seen in the following table:

Table 8. The results of testing the effect of Papaya Leaf Simplicia (Carica Papaya L.) on the adequacy of breast milk in infants aged 6 months

\begin{tabular}{cccc}
\hline Test & Average & Statistics & Sig. \\
\hline $\begin{array}{c}\text { Not } \\
\text { Consumed }\end{array}$ & 697,174 & $-4,182$ & 0,000 \\
Consumed & 757,391 & & \\
\hline
\end{tabular}

Based on the table above, it can be seen that the results of testing the effect of Papaya Leaf Simplicia (Carica Papaya L.) on the adequacy of breast milk in infants aged 6 months resulted in a statistical t-test of -4.182 with a significance value of 0.000 . It can be seen that the significance < alpha (5\% or 0.05$)$, so H0 is rejected and $\mathrm{Ha}$ is accepted. Therefore, it can be stated that there is a significant effect of Papaya Leaf Simplicia (Carica Papaya L.) on the Adequacy of Breastfeeding in Infants Age $\leq 6$ Months in the Working Area of the Gunung Tua Health Center, Kab. North Padang Lawas in 2021. The average result of consuming Papaya Leaf Simplicia (Carica Papaya L.) is higher than not consuming Papaya Leaf Simplicia (Carica Papaya L.) proven to be effective in increasing breast milk adequacy in infants aged 6 months.

\section{CONCLUSION}

1. There is an effect of Adequacy of Breastfeeding on Infants Age 6 Months after being given Papaya Leaf Simplicia in the Working Area of Gunung Tua Health Center, North Padang Lawas Regency in 2021

2. Insufficient breast milk for infants aged 6 months before being given Papaya Leaf Simplicia in the Working Area of the Gunung Tua Health Center, North Padang Lawas Regency in 2021.

3. There is Sufficient Breastfeeding in Infants Age 6 Months after being given Papaya Leaf Simplicia in the Working Area of the Gunung Tua Health Center, Kab. North Padang Lawas Year 2021.

Suggestions in this research are:

1. Advice for health workers

Suggestions for health workers is that socialization is needed in the community about the effectiveness of Papaya Leaf Simplicia (Carica Papaya L.) for adequate milk production in infants. Health workers need to conduct socialization about the correct dosage, timeliness of use, how to use and the correct selection of ingredients so that the right Papaya Leaf Simplicia (Carica Papaya L.) will be obtained.

2. For further research, other ingredients can be added for the effectiveness of papaya leaf simplicia on breast milk production, such as green beans or Moringa leaves

\section{ACKNOWLEDGEMENTS}

Author thanks Nur Aliyah Rangkuti, Rya Anastasya Siregar, Elvi Suryani, Ratna Dewi Siregar, Maryam Latifah Harahap. In most cases, sponsor and financial support. 


\section{REFERENCES}

[1] Adiningrun, H, "Exclusive breastfeeding", Jakarta Timur: Salsabila, 2015.

[2] Astuti, S, "Postpartum and Breastfeeding Midwifery Care", Jakarta: Penerbit Erlangga, 2015

[3] Graharti, R. Et Al, "The Effect Of Papaya ( Carica Papaya L .) Towards Breast Milk Production In Breastfeeding Mothers”, 8 April, 2018, Pp. 39-43.

[4] Indonesia Dictionary, 2019

[5] Indonesian Ministry of Health, "Republic of Indonesia Health Profile", 2017.

[6] Kumalasari, I, " Antenatal, Intranatal, Postnatal Newborn Care And Contraception ", Jakarta Selatan: Salemba Medika, 2015.

[7] Kusumaningrum, I. D, "Surya Medika Potential Papaya Leaves (Carica Papaya L)", 12(2), 2017, Pp. 120-124.

[8] Mansyur, N, "Postpartum Midwifery Care", Malang: Selaksa Media, 2015.

[9] Martalia, D, "Postpartum and Breastfeeding Midwifery Care", Yogyakarta: Pustaka Pelajar, 2015.

[10] Martalia, D, " Midwifery Care for Postpartum Mothers", Yogyakarta: Gosyen Publishing, 2015.

[11] Maryunani, A, "Early Initiation of Breastfeeding, Exclusive Breastfeeding and Lactation Management", Jakarta Timur: Cv.Trans Info Media, 2015.

[12] Nafi'ah, R, “Training on Making Instant Sweet Powder of Papaya Leaves as an Effort to Streamline Mother's Milk in Karangbener Village Rt 02 Rw 07 Bae Kudus District", Journal Of Chemical Information And Modeling, 53(9), 2019 Pp. 1689-1699. Doi: 10.1017/Cbo9781107415324.004.

[13] Nasir, A, “Textbook: Health Research Methodology”, Yogyakarta: Nuha Medika, 2014.

[14] Naufalin, R, "Papaya. Yogyakarta: Plantaxia, 2015

[15] Notoatmodjo, S, " Health Research Methodology", Jakarta: Pt. Rineka Cipta, 2017

[16] Pollard, M, " Evidence-Based Breastfeeding", Jakarta: Buku Kedokteran Egc, 2016

[17] Gunung Tua Health Center, " Recording of Exclusive Breastfeeding Achievements for March-August, 2019.

[18] Ristu Wiyani, I, " The Effect of Giving Papaya Leaf Powder (Carica Papaya) on the Smooth Breastfeeding of Postpartum Mothers ", Jurnal Darul Azhar, 7(1), 2019, Pp. 45-53.

[19] Rukiyah, A. Y, "Midwifery Care III (Postnatal Care)", Jakarta Timur: Cv. Trans Info Media, 2016

[20] SDG's ditjen BG-KIA," Health in the Framework of Sustainable Development Goals" ,2015.

[21] Setiawan, D, " Health Research Methodology ", Yogyakarta: Graha Ilmu.2015.

[22] Subagio, S. U, " Increasing the Adequacy of Breast Milk Production in Postpartum Mothers Using Sweet Potato Leaf Decoction in the Work Area of the Kesesi I Public Health Center Pekalongan ", 8(2), 2019, Pp. 137-142.

[23] North Sumatra, "Health Profile", "North Sumatra Health Profile" , Journal Of Chemical Information And Modeling, 53(9), 2017, Pp. 16891699. Doi: 10.1017/Cbo9781107415324.004.

[24] Teachers, T, " Midwifery Care for Newborns ", Yogyakarta: Pustaka Pelajar, 2014.

[25] Turlina, L. And Wijayanti, R, " The Effect of Giving Papaya Leaf Powder on Smooth Breastfeeding in Postpartum Mothers at Bpm Ny. Hanik Dasiyem, Amd.Keb in Kedungpring, Lamongan Regency ", Surya, 07(01), 2015, Pp. 1-9.

[26] Yanti, D, " Postpartum Midwifery Care ", Bandung: Pt. Refika Aditama, 2015 